\title{
臨床講座
}

\section{歯科インプラントの最新の潮流 一低侵襲インプラントー} 尾 関 雅 彦

The New Trend in Implant Dentistry

- Minimally Invasive Implant-

\section{Masahiko OZEKI}

Department of Prosthodontics, Showa University School of Dentistry

\section{臨床のポイント}

インプラント手術にともなう外科的侵襲をできるだけ小さくすることにより，患者の肉体的 苦痛や経済的負担を軽減するだけでなく, 手術の手間や偶発症のリスクを回避し, 最終補綴処 置までの治療期間を短縮することは，患者と術者の双方にとって非常に望ましい治療法であ る。このような観点から, 歯科インプラントの最新の潮流として, 埋入手術から最終補経まで のインプラント治療を低侵襲にしょうとする試みがある。本稿で紹介した自家骨移植を回避す るための数々の手法や，インプラント埋入本数の少数化の試み，あるいは最新のコンピュータ ーガイドを併用した Flapless surgery（Non-flap surgery）によるインプラント治療は, 臨床 的に非常に有用であり，今後ますます普及すると思われる。 


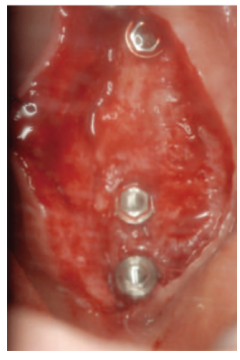

図 1

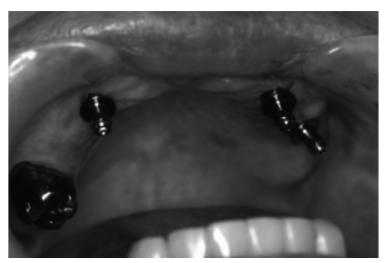

図 5

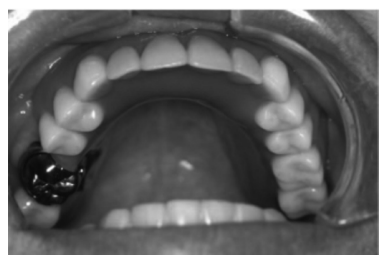

図 8

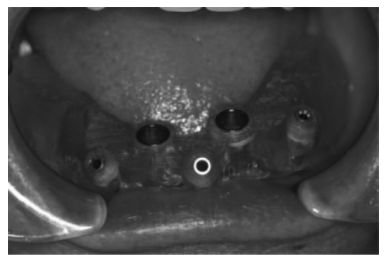

図 11

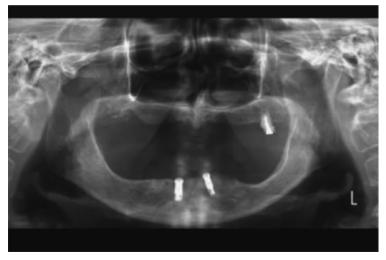

図 14

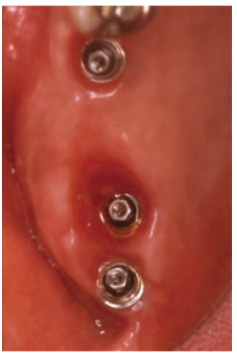

図 2

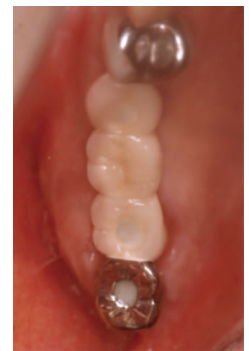

図 3

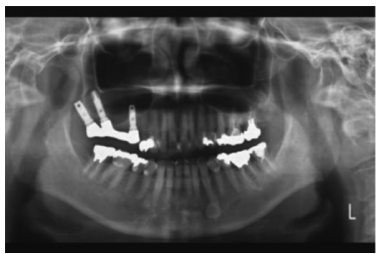

図 4

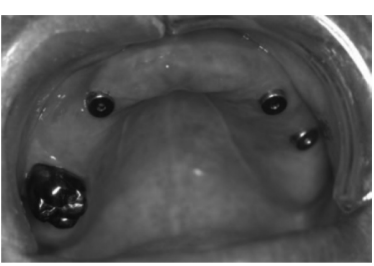

図 7

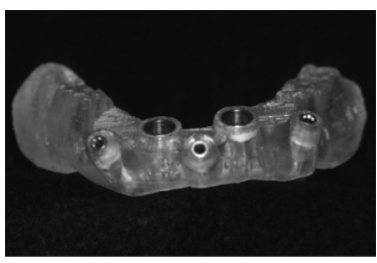

図 10

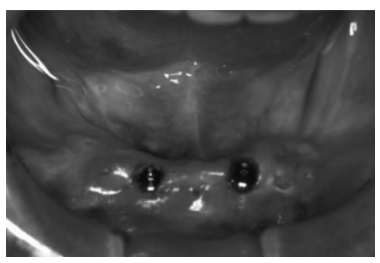

図 13

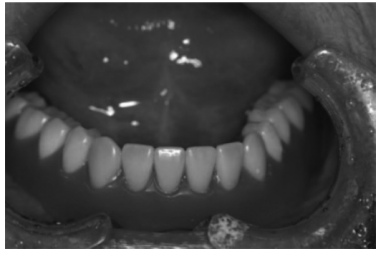

図 16

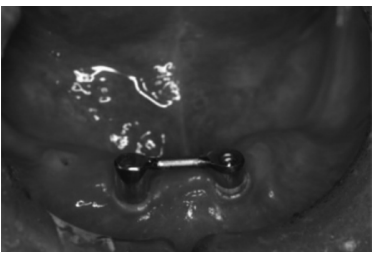

図 15

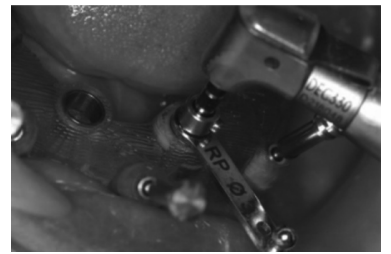

図 12 
こんにちの歯科臨床において骨結合型インプラント は，補綴治療の選択肢のひとつとして応用される時代に なっている.とくに近年の歯科インプラントの発展にと もない，従来は不可能とされていた顎骨欠損や骨萎縮を 伴う症例に対して，しばしば自家骨移植や骨補填材を用 いた顎骨再建術や骨造成術，あるいは仮骨延長術などを 併用したインプラント埋入手術が行われている。

しかしながらこれらの方法は手術侵襲が大きく，肉体 的苦痛や経済的負担あるいは治療期間の延長などの面 で，患者にとっては必ずしも満足度の高い治療法となら ないことも多い.

インプラント手術にともなう外科的侵襲をできるだけ 小さくすることにより, 患者の肉体的苦痛や経済的負担 を軽減するだけでなく，手術の手間や偶発症のリスクを 回避し, 最終補経処置までの治療期間を短縮すること は，患者と術者の双方にとって非常に望ましい治療法で ある。

このような観点から，歯科インプラントの最新の潮流 として, 埋入手術から最終補経までのインプラント治療 を低侵襲にしようとする試みがある。そこで本稿では， 現在行われている低侵襲インプラント治療について解説 する。

\section{1. 上顎洞底挙上術に関連して}

上顎臼歯部欠損で歯槽骨吸収が著しい（垂直的骨量が そしい）症例にインプラント埋入するためには，上顎洞
前壁を開空して上顎洞底粘膜を剥離挙上し，上顎洞底に 自家骨などの骨補填材を移植する上顎洞底挙上術（上顎 洞骨造成術）がしばしば行われてきた。しかしながらこ の上顎洞底挙上術が行われた場合には, recipient site （上顎）とdonor site（しばしばオトガイ部や下顎枝） の術後腫脹や疼痛が著しく，時には自家骨採取にともな う下口唇知覚麻痺などの偶発症を生じることもある。ま た骨造成部位が広範囲なために，口腔内からの自家骨採 取量では不十分で, donor を腸骨や脛骨など口腔外に求 める必要がある場合には1), 一般の歯科医院での治療は 難しく, 入院設備が完備され専門医がいる大病院で行わ れることが多い. 近年，垂直的骨量が乏しい上顎臼歯部 欠損症例に対するインプラント埋入手術において, 従来 までの上顎洞底挙上術（上顎洞骨造成術）の手術侵襲を 軽減して術後合併症の発現を防止するとともに, 通院手 術を可能にしてインプラントの適応症を広げようとする 幾つかの方法が考案されている。

1) ソケットリフト

歯槽頂部に形成したインプラント埋入窩にオステオ トームを挿入し，上顎洞底骨を桘打して洞底部粘膜を 挙上し，少しでも長いインプラントを埋入する手技であ る ${ }^{2)}$. 数年前までは既存骨が $5 \mathrm{~mm}$ 以上ある症例が適応 症とされ， $3 \mathrm{~mm}$ 位の挙上が可能とされていたが，昨今 では,さらに少ない既存骨に対して $5 \mathrm{~mm}$ 以上の挙上 を行っている報告例もある。挙上した洞底部のスペース には，自家骨や各種の骨補填材を填塞することが多い.

図 1 症例 1 骨移植なしの上顎洞底挙上術と傾斜埋入を併用して, 875 部にインプラントを 3 本埋入した。

図 2 症例 1 最終補経後でインプラントブリッジ装着前の上顎右側臼歯部.

図 3 症例 1 最終補綴物（インプラントブリッジ）を装着した上顎右側臼歯部。

図 4 症例 1 最終補綴後のオルソパントモ X 線写真.

図 5 症例 2 歯肉粘膜弁を形成することなく，3|35 部に Flapless surgery（Non-flap surgery）でインプラン トを 3 本埋入した。埋入部からの出血はごく微量である。

図 6 症例 2 インプラント埋入直後のオルソパントモ X 線写真.

図 7 症例 2 最終補経後でインプラント支持型の可撤性部分床義歯を外した上顎. $3 \mid 35$ 部のインプラントに根 面アタッチメントが連結されている。

図 8 症例 2 最終補綴物（インプラント支持型の可撤性部分床義歯）を装着した上顎. 義歯の維持安定は良好 で，機能時の義歯の動摇はほとんどない。

図 9 症例 2 最終補綴物（インプラント支持型の可撤性部分床義歯）の粘膜面. $3 \mid 35$ 部に磁性アタッチメント を使用し，口蓋部分は開放されている。

図 10 症例 3 PC 画面上のシミュレーション手術で設計し，CAD/CAM により作製したサージカルテンプレー 卜.

図 11 症例 3 下顎にサージカルテンプレートを装着した口腔正面.

図 12 症例 3 サージカルテンプレートに従ってインプラント埋入窩を形成し, 歯肉粘膜弁を翻転することなく Flapless（Non-flap）でインプラントを埋入した。

図 13 症例 3 2| 2 部にインプラント埋入直後の口腔内正面. Flapless surgery（Non-flap surgery）によるイン プラント埋入なので，埋入部からの出血はごく微量である.

図 14 症例 3 インプラント埋入直後のオルソパントモ $\mathrm{X}$ 線写真.

図 15 症例 3 最終補経後でインプラント支持型の可撤性全部床義歯を外した下顎. $\overline{2} \mid 2$ 部のインプラントにバ ーアタッチメントが連結されている。

図 16 症例 3 最終補綴物（インプラント支持型の可撤性全部床義歯）を装着した下顎。義歯の維持安定は良好で ある。 
槌打にともなう患者の不快感を回避するために，近年で は専用ドリルを用いて，より低侵襲性に挙上する手技も 考案されている31.

\section{2）自家骨以外の骨補填材}

挙上した洞底部のスペースに填塞する補填材として は，従来から自家骨が最もよいとされてきた。しかしな がら自家骨採取に伴う外科侵襲を軽減するために，欧米 では 10 年以上前から他家骨や異種移植骨あるいは生体 材料が使用されてきた。他家骨としては凍結乾燥骨が， 異種移植骨としては Bio-Oss に代表されるウシ由来の アパタイト顆粒などが，また生体材料としてはオスフェ リオンなどの $\beta$-TCP や各種ハイドロキシアパタイトが 単独で，あるいは自家骨と併用して使用されている。

3）骨補填なしの上顎洞底挙上術

上顎洞が血餅で満たされていれば，上顎洞底の骨や骨 膜から新生骨が誘導されることを期待して，挙上した洞 底部のスペースになんら骨補填材を填塞しない方法であ る ${ }^{4)}$ ，自家骨を採取する場合よりも，はるかに低侵襲性 となる。

4) Hydraulic Sinus Condensing (HSC 法)

歯槽骨頂から上顎洞底の骨を小さな円形バーで穿孔す る際に，歯科用タービンの水圧を利用して洞底粘膜をわ ずかに剝離挙上し，その後，徐々に拡大した洞底粘膜の 挙上スペースにBio-Oss を主とする骨補填材を填塞し た後に，埋入窩を形成してインプラントを埋入する手技 である ${ }^{5)}$.上顎洞前壁を開空することがないので，術後 の腫脹や疼痛が非常に軽い.

5）インプラントの傾斜埋入

インプラントの上顎洞への穿孔を避けるために，上顎 洞前壁，臼後結節部あるいは上顎洞内側壁の既存骨にイ ンプラントを傾斜させて埋入する手技である ${ }^{6,7)}$. 通常 のインプラント埋入手術と同程度の手術侵襲ですむ。 イ ンプラントを埋入する位置と方向が，将来の補綴上部構 造と合致している必要があり，術前の綿密な検査と診断 が重要となる。

\section{2. 骨造成，顎堤拡大および移植骨採取に関連して}

歯牙欠損部の残遺歯槽骨が煩舌的あるいは垂直的に骨 吸収が進んで，インプラントの埋入が難しい場合や，補 経後のインプラント周囲歯肉の形態に審美性障害が生じ ると予想される場合には，インプラント埋入手術と関連 してしばしばブロック状の自家骨や粉砕骨，あるいは各 種メンブレンを用いた骨造成術が行われる。また骨切り 術を応用したスプリットクレスト法などによる水平的歯 槽骨の拡大手術や，仮骨延長術などによる垂直的あるい は水平的な歯槽骨顎堤拡大手術も行われてきた。しかし
ながら，自家骨採取や骨切り術の手術侵襲を最小にしよ うとする手法が幾つか考案されている。

1）ボーンスクレーパー

ボーンスクレーパーによる自家骨採取は，インプラン 卜埋入部周囲の皮質骨面をボーンスクレーパーで削りと る方法である。Donorを必要としないので手術侵襲は 小さいが，骨採取量には制限がある。

2) ボーントラップ

インプラント埋入窩をドリルで形成する際に，ドリル 表面に付着したり，ボーントラップに吸引集積された骨 削片（骨屑）を自家骨移植する方法である。しかしなが ら骨削片（骨屑）を細菌培養したところ，多量の口腔常 在菌が同定されたとの研究報告があり，注意を要する。

3）ピエゾサージェリー

超音波振動を利用して骨を切断したり穿孔する方法で ある ${ }^{8)}$. ドリルや電動ソーなどの切削道具と比較して, 切りしろが非常に少ないので，骨切り術の際に骨組織を 可及的に保存でき，またdonor site からの移植骨片採 取に無駄がない。とくに上顎洞底挙上術に用いた場合に は，洞底粘膜の損傷裂開を防止できる。

4）自家骨以外の骨補填材

骨造成に際して，自家骨採取に伴う外科侵襲を軽減す るために, 他家骨 (七ト凍結乾燥骨), 異種移植骨 (Bio-Oss な゙)，生体材料（ $\beta$-TCP やハイドロキシア パタイトなど）を自家骨と併用したり，単独で使用する ことがある．厚労省未認可の材料も多く，本邦での適用 が難しいこともある。

5) Ridge expansion

煩舌的に狭小な歯槽骨を低侵襲性に拡大する方法で, オステオトーム，オウギュメンテーター（骨錐）あるい は専用の拡大装置などを使用する。骨切り術を応用した スプリットクレスト法や仮骨延長術よりも低侵襲性の手 術である.しかしながら拡大された菲薄な煩側皮質骨片 が，数か月後に吸収してしまう場合もあり，この方法を 適用するには注意を要する。

\section{3. インプラントのサイズの細短化}

インプラント埋入部位の骨造成を回避して手術侵襲を 少しでも軽減するために，直径の細いインプラント (Narrow implant) や長径の短いインプラント（Short implant）を使用することがある。

1）細いインプラント（Narrow implant）

顎骨の形態が良好な場合には，一般に直径が3.75〜 $4.0 \mathrm{~mm}$ のレギュラーサイズのインプラントを埋入する ことが多い.しかしながら残遺歯槽骨の煩舌的幅径が狭 小で，直径が 3.75〜 $4.0 \mathrm{~mm}$ あるレギュラーサイズのイ 
ンプラントを埋入することが難しい場合には，骨造成や 顎堤拡大などの手術を回避するために，直径が3.0〜 $3.25 \mathrm{~mm}$ の細いインプラント（Narrow implant）を使 用することがある ${ }^{9)}$.

2) 短いインプラント (Short implant)

垂直的骨量（高さ）がそしい場合に，長径が $6 \mathrm{~mm}$ や $7 \mathrm{~mm}$ の短いインプラント（Short implant）を埋入 することがある。数年前まで上顎症例では，10 $\mathrm{mm}$ 以 上のインプラントと比較すると, $10 \mathrm{~mm}$ 未満の短いイ ンプラントの生着率は悪いと言われていた。しかしなが ら近年，上顎臼歯部でも複数本の $7 \mathrm{~mm}$ あるいは 8.5 $\mathrm{mm}$ の短いチタンインプラントを埋入し, 支台インプ ラントを連結固定すれば，良好な治療成績が得られると の報告もある10).

\section{4. インプラント埋入本数の少数化}

1) All on 4

無歯顎に対して下顎は 4 本，上顎は 4〜 6 本のインプ ラントを埋入し，即時に補綴上部構造（暫間ブリッジ） を装着して咬合負荷を加える手法である ${ }^{11,12)}$ ，下顎では オトガイ孔とオトガイループを，また上顎では上顎洞底 を避けるために，小臼歯部に埋入するインプラントの歯 冠歯根軸を遠心方向へ傾斜させることと，屈曲型アバッ トメントを用いてアクセスホールを第 1 大臼歯部に設置 することが，従来までのインプラント治療と異なる。従 来の無歯顎のインプラントブリッジにおけるインプラン 卜手術と比較して，大白歯部に埋入することはなく，支 台インプラントは最少本数なので，埋入手術にともなう 外科侵襲は軽減される。

2）インプラント支持型可撤性床義歯 Implant supported removable prosthesis (ISRP)

無歯顎や多数歯欠損に対して，インプラントを可撤性 床義歯の支台装置として利用することにより，上部構造 を固定性義歯（ブリッジ）に設計した場合よりもインプ ラントの埋入本数は少数となり，手術侵襲は軽減され る.とくに遊離端欠損では，遠心部に埋入した最少本数 のインプラントに咬合支持をさせることで，義歯床の沈 下が抑制される ${ }^{13)}$.

\section{Flapless surgery}

顎骨の形状が良好なために，歯肉粘膜を切開剝離して 骨面を直視しなくても，適切な位置と方向にインプラン 卜埋入ができる場合に，歯肉表面から顎骨内へ直接にド リリングして埋入窩を形成し，インプラントを埋入する Flapless surgery が近年普及しつつある ${ }^{14)}$. 切開剝離を しないので出血量が少なく，縫合を必要としないので手
術時間も短縮され, 術後の腫脹や疼痛も非常に軽く, 最 も低侵襲性のインプラント手術といえる。しかしながら Flapless surgery は骨面を直視しないで盲目的に行う手 技なので，不適切な位置と方向に埋入窩を形成する危険 性がある。そのために Flapless surgery でインプラン トを埋入する際には，術前の診査診断に頼るだけでな く, 埋入窩形成時における視診触診に基づく的確な術中 診断が重要である。

\section{6. コンピューターガイドによるインプラント治療} 近年のコンピューターソフトの発達と普及により, 顎 骨の形状を 3 次元的に解析しながら PC 画面上でシミュ レーション手術を行い, 想定する最終補綴物に対して最 適な支台インプラントの位置や方向, ならびにサイズや 本数までもが決定できる ${ }^{15)}$.さらに，埋入窩のドリル形 成とインプラント埋入が，シミュレーション手術どおり に行えるようなサージカルテンプレート（ステント）を 用いることにより，インプラント埋入手術が安全，確実 かつ低侵襲性に行える。

当科において低侵襲インプラントによりインプラント 治療を行った 3 症例を紹介する。

症例 1 . 骨移植なしの上顎洞底挙上術とインプラン 卜傾斜埋入を併用した症例

患者は 60 歳の女性で，765 次損. 上顎右側臼歯部 の骨量は乏しく，骨移植なしの上顎洞底挙上術と傾斜埋 入を併用して Fixture 3 本埋入し（図 1)，インプラ ントブリッジとした（図 2～図 4).

症例 2. Flapless surgery で行ったインプラント支持 型可撤性床義歯の症例

患者は60 歳の女性で，654321|1234567 欠損. 上顎に Flapless surgery (Non-flap surgery) でFixtureを 3 本埋入し（図 5, 図6)，インプラント支持型 の可撤性部分床義歯とした（図 7〜図 9).

症例 3. コンピューターガイドによるインプラント 治療で行ったインプラント支持型可撤性床義歯の症例

患者は 83 歳の女性で，下顎無歯顎，上顎多数歯欠損. $\mathrm{PC}$ 画面上のシミュレーション手術で設計し, CAD/ CAM により作製したサージカルテンプレートにしたが って，下顎に Flapless surgery (Non-flap surgery) で Fixture を 2 本埋入し（図 10～図 14）, インプラント支 持型の可撤性全部床義歯とした（図 15, 図 16).

このような低侵襲インプラントの治療方法が普及する ことにより，今後はインプラントを用いた補綴治療がま すます重要性を帯びると思われる。 


\section{文献}

1) Miranda SL, Fonseca APZ, Guanieri M : Evaluation and donor site morbidity of tibial bone graft in sinus lift operation. Oral Surg, 1:135-139, 2008

2) Summers RB: The osteotome technique: Part 3-Less invasive methods of elevating the sinus floor. Compend Contin Educ Dent, 15:698-704, 1994

3) Kimura A : Drill device for sinus lift [Article]. Implant Dent, 14:340-343, 2005

4) Sohn D, Lee J, Ahn M, Shin H : New bone formation in the maxillary sinus without bone grafts [Basic and Clinical Research]. Implant Dent, 17 : 321-331, 2008

5) Leon C, Jennifer C:An 8-Year retrospective study: 1,100 patients receiving 1557 implants using the minimally invasive hydraulic sinus condensing technique. J Periodontol, 76 : 482-491, 2005

6) Aparicio C, Prales P, Rangert B : Tilted implant as an alternative to maxillary sinus grafting: a clinical, radiologic, and periotest study. Clin. Implant Dent Relat Res, 3:39-49, 2001

7) Calandriello R, Tomatis M : Simplified treatment of the atrophic posterior maxilla via immediate/ early function and tilted implants. Clin Implant Dent Relat Res, 7 (Suppl 1) : S1-12, 2005

8) Vercellotti T, De Paoli S, Nevins M : The piezoelectric bony window osteotomy and sinus membrane elevation: Introduction of a new technique for simplification of the sinus augmentation procedure. Int J Perio Rest Dent, 21 : 561-567 2001

9) Romeo E, Lops D, Amorfini L, Chiapasco M, Ghisolfi M, Vogel G : Clinical and radiographic evaluation of small diameter $(3.3 \mathrm{~mm})$ implants followed for 1-7 years. Clin Oral Implant Res, $17: 139-148,2006$

10) Renouard F, Nisand D: Short implant in the severely resorbed maxilla: a 2-year retrospective clinical study. Clin Implant Dent Relat Res, 7 (Suppl 1) : 104-110, 2005

11) Malo P, Rangert B, Nobre M. : All-on-4 immediate-function concept with Brånemark system implants for completely edentulous mandible: a retrospective clinical study. Clin Implant Dent Relat Res. 5 : 2-9, 2003

12) Maló P, Rangert B, Nobre M : "All-on-Four" immediately function concept with Brånemark system implants for completely edentulous maxillae: a 1-year retrospective clinical study. Clin Implant Dent Relat Res, 7 (Suppl 1) : 88-94, 2003

13) Ohkubo C, Kobayashi M, Suzuki Y, Hosoi T : Effect of implant support on distal-extension removable partial dentures: In vivo assessment. Int J Oral Maxillofac Implants, $23: 1095-1101$, 2008

14) Becker W, Goldstein M, Becker BE, Sennerby L : Minimally invasive flapless implant surgery: A prospective multicenter study. Clin Implant Dent Relat Res, 7 (Suppl 1) : 21-27, 2005

15) van Steenberghe D, Glauser R, Blonback U, Andersson M, Schutyser F, Pettersson A, Wendelhag I: A computed tomographic scan-derived customized surgical template and fixed prosthesis for flapless surgery and immediate loading of implants in fully edentulous maxillae. Clin Implant Dent Relat Res, 7 (Suppl 1) : 111-120, 2005 